Maurer School of Law: Indiana University

Digital Repository @ Maurer Law

\title{
Governing Catastrophes: Security, Health and Humanitarian Assistance
}

David P. Fidler

Indiana University Maurer School of Law, dfidler@indiana.edu

Follow this and additional works at: https://www.repository.law.indiana.edu/facpub

Part of the Health Law and Policy Commons, and the International Public Health Commons

\section{Recommended Citation}

Fidler, David P., "Governing Catastrophes: Security, Health and Humanitarian Assistance" (2007). Articles by Maurer Faculty. 451.

https://www.repository.law.indiana.edu/facpub/451

This Article is brought to you for free and open access by the Faculty Scholarship at Digital Repository @ Maurer Law. It has been accepted for inclusion in Articles by Maurer Faculty by an authorized administrator of Digital Repository @ Maurer Law. For more information, please contact rvaughan@indiana.edu. 


\title{
Governing catastrophes: security, health and humanitarian assistance
}

\section{David P. Fidler}

David P. Fidler is the James Louis Calamaras Professor of Law, Indiana University School of Law; Director, Indiana University Center on American and Global Security.

\begin{abstract}
Recent catastrophes, and predictions of an increasing potential for more, have stimulated thinking about the best policy responses to these threats. This article explores how security concepts influence catastrophe governance. The article considers how globalization affects thinking about catastrophes and describes ways in which catastrophes have been conceptualized as governance challenges, such as the human rights approach to the provision of health and humanitarian assistance. The article explains how health and humanitarian assistance experienced "securitization" in the post-cold war period, a development that challenges rights-based strategies and creates complex and controversial implications for the prevention, protection and response functions of catastrophe governance.
\end{abstract}

We live in a world haunted by catastrophes past, present and pending. From the past come memories of devastating world wars that scarred humanity deeply. In the present, we watch disease and natural disasters wreak havoc around the world. Portents for the future offer more ferocious pandemics, terrorist use of nuclear, radiological, biological or chemical weapons, and planetary pain and suffering linked to unabated environmental degradation. ${ }^{1}$ Catastrophes are, of course, not new to human societies, but what is new is the nature of the globalized context in which they occur. We not only see large-scale disasters and the human suffering they cause unfold through communications technologies, but we also have 
developed global capabilities to provide humanitarian assistance to victims just about anywhere in the world. This context makes us more aware of catastrophes and the shared responsibilities of preparing for, protecting against and responding to them.

This awareness confronts us with the challenge of governing catastrophes before, during and after their occurrence. Governance requires framing policy challenges in ways that facilitate effective strategies and tactics. Preparedness and response to catastrophes are increasingly framed as security challenges rather than humanitarian problems. The reconceptualization of health and disaster relief as security issues directly contributes to thinking about catastrophes in security terms. Although in many ways understandable, framing catastrophe governance through the lens of security creates significant complexities and controversies concerning the provision of humanitarian assistance to populations affected by catastrophic events.

This article explores the emerging contours of catastrophe governance in order to illuminate how the security framework affects the protection of health and the provision of humanitarian assistance. It analyses how thinking about disaster relief and health has shifted from a rights-based philosophy to approaches grounded in security concepts. The article then examines issues that arise when approaching catastrophe governance under a security paradigm. In this approach, considerations of the source, scale and severity of a catastrophic event affect political calculations concerning sovereignty and security in ways that shape the effectiveness and sustainability of catastrophe governance. The security paradigm produces a double-edged effect for catastrophe governance that it is important to understand, because large-scale disasters, both man-made and naturally occurring, may increasingly affect the protection of health and the provision of humanitarian assistance in the future.

\section{Catastrophes and globalization}

Dictionaries typically define a "catastrophe" as a large-scale, sudden and disastrous event that causes widespread death, destruction and suffering. ${ }^{2}$ History is replete with famous catastrophes, including devastating military

1 For considerations on the future of catastrophes in human societies, see Richard A. Posner, Catastrophe: Risk and Response, Oxford University Press, Oxford, 2004; Jared Diamond, Collapse: How Societies Choose to Fail or Succeed, Penguin, New York, 2005; and Thomas Homer-Dixon, The Upside of Down: Catastrophe, Creativity, and the Renewal of Civilization, Island Press/Shearwater Books, Washington, DC, 2006.

2 See, e.g., New Shorter Oxford English Dictionary, Oxford University Press, Oxford, 1993, p. 351 (defining "catastrophe" as a "sudden or widespread or noteworthy disaster; an extreme misfortune"). This definition overlaps with other concepts, such as complex emergencies, that also draw attention to policy and governance questions raised by significant man-made or natural disasters. See, e.g., Ronald Waldman, "Responding to catastrophes: a public health perspective", Chicago Journal of International Law, Vol. 6 (Winter) (2006), p. 553. Some have challenged the traditional definition of catastrophe by pointing out that the world also faces "slow motion" catastrophes, such as HIV/AIDS and climate change. See Raymond T. Pierrehumbert, "Climate change: a catastrophe in slow motion", Chicago Journal of International Law, Vol. 6 (Winter) (2006), p. 573; and Tony Trahar, "Anglo American and the road to ART", Radar Perspective, December 2003/January 2004, p. 27 (describing HIV/AIDS as a "slow motion catastrophe"). 
conflicts, decimating disease epidemics and destructive natural disasters. Industrial and technological revolutions created the potential for man-made catastrophes involving accidents to expose populations and ecosystems to harmful substances (e.g. the chemical accident at Bhopal, India, in 1984; the nuclear accident at Chernobyl, Soviet Union, in 1986). In terms of the history of human civilizations, efforts to construct governance regimes involving international co-operation to prevent, protect against and respond to large-scale disasters have appeared only recently. These governance efforts begin seriously with efforts made in the latter half of the nineteenth century to shield civilian populations from armed conflict and to protect and care for those wounded in war. ${ }^{3}$ The examples set in this domain inspired others, who envisioned ways to improve international assistance to populations devastated by natural disasters such as earthquakes or famines. ${ }^{4}$ Still later emerged attempts to harness better international co-operation to alleviate the death and suffering inflicted by disease on human populations, particularly those in poor, poverty-stricken countries. ${ }^{5}$

The development of international governance strategies for responding to catastrophes owes much to the processes of globalization sensed in the latter half of the nineteenth century. Political, economic and technological developments in the nineteenth century permitted those concerned about the impact of catastrophes not only to refine perceptions of an interdependent humanity but also to imagine the material ways and means to organize and provide humanitarian assistance to those harmed by large-scale disasters. ${ }^{6}$ This earlier phase of globalization produced the ideational and material climate that fostered the development of governance efforts to provide humanitarian assistance to people affected by war and disasters. This period also saw states co-operating to address disease epidemics and industrial pollution that could cause cross-border harm. ${ }^{7}$ All these efforts included the use of international law, the creation of intergovernmental organizations and the involvement of non-state actors dedicated to health or humanitarian causes.

Contemporary concerns about catastrophe governance echo the nineteenth century origins of this area of world affairs. In fact, new manifestations of globalization heighten awareness of both the human suffering related to

3 See, e.g., John Hutchinson, Champions of Charity: War and the Rise of the Red Cross, Westview Press, Boulder, 1996; David P. Forsythe, The Humanitarians: The International Committee of the Red Cross, Cambridge University Press, Cambridge, 2005.

4 Peter Macalister-Smith, International Humanitarian Assistance: Disaster Relief Actions in International Law and Organization, Kluwer Law International, Dordrecht, 1985, pp. 17-21; John Hutchinson, "Disasters and the international order: earthquakes, humanitarians, and the Ciraolo Project", International History Review, Vol. 22 (2000), p. 1; John Hutchinson, "Disasters and the international order - II: the International Relief Union”, International History Review, Vol. 23 (2001), p. 253.

5 Neville M. Goodman, International Health Organizations and Their Work, 2nd edn, Churchill Livingstone, London, 1971, p. 389.

6 Admittedly, concepts of an interdependent humanity were often Eurocentric and did not always extend to non-European civilizations experiencing imperialism and exploitation at the hands of European countries.

7 David P. Fidler, "The globalization of public health: the first 100 years of international health diplomacy", Bulletin of the World Health Organization, Vol. 79 (2001), pp. 843-4. 
catastrophic events and the global capabilities available to provide assistance to those in need. This awareness and these capabilities converge to produce insights on the governance mechanisms that emerged in the latter half of the nineteenth century and first half of the twentieth century. The insights identify the inadequacy of these co-operative mechanisms and urge states and non-state actors to reform strategies for preventing, protecting against and responding to catastrophic events. This approach involves efforts to reconceptualize how we think about catastrophes as governance challenges. Some reconceptualizations frame catastrophe governance in security terms rather than as a charitable, humanitarian or altruistic activity. The following parts of this article explore this important and controversial shift in strategic thinking on catastrophe governance.

\section{Conceptualizing catastrophe governance}

\section{Pollution and disease: regimes addressing direct, cross-border harms}

International co-operation on the cross-border spread of harms resulting from infectious disease epidemics and industrial pollution began in the nineteenth century. In terms of epidemics, states convened numerous international sanitary conferences, starting in 1851 in response to serious outbreaks involving cholera and the plague, and countries eventually negotiated a series of international sanitary conventions from the late nineteenth century to the Second World War. ${ }^{8}$ The mortality and fear caused by some cholera outbreaks made those epidemics disastrous events for a number of countries, and fear of further disease-related calamities provided incentives for international co-operation. Equally, or perhaps more, important were state interests in reducing the burdens on trade and commerce produced by national efforts to keep foreign diseases at bay (e.g. economic costs imposed by quarantine measures).

Approaches to the transboundary spread of diseases involved the duty of countries to notify other states of outbreaks of specific diseases in their territories with potential for cross-border spread. ${ }^{9}$ Advance notification would allow countries to anticipate and potentially control any importation of microbial threats. The international sanitary conventions did not, however, require states to make efforts to prevent disease epidemics from occurring within their own territories and spilling over into other countries. Nor did these treaties impose duties on states to provide assistance to countries badly affected by disease epidemics.

Industrialization created greater potential for transboundary pollution, and states crafted international regimes to address it, particularly in the context of international watercourses. ${ }^{10}$ In terms of transboundary pollution, early treaties

8 For an analysis of this history, see David P. Fidler, International Law and Infectious Diseases, Clareudon Press, Oxford, 1999, pp. 21-57.

9 Ibid., pp. 42-7.

10 Patricia Birne and Alan Boyle, International Law and the Environment, Clareudon Press, Oxford, 1992, pp. 224-6. 
contained strict prohibitions, but international co-operation gradually adopted an approach that only prohibited pollution that would seriously harm the rights of other states, such as the release of very hazardous substances. ${ }^{11}$ In these contexts, states did not frame transboundary pollution as a catastrophic problem but rather as an issue that required balanced regulation between the economic interests of countries involved.

In these examples, states conceived of epidemics and transboundary pollution occurring in other countries as exogenous threats to their national interests that required co-operation in order to mitigate potential cross-border impact. The international co-operation on epidemic diseases developed through fear of disease calamities, but this regime evolved in ways that lessened its connection with protecting against future disasters. As noted more below, the notification mechanisms used in the international sanitary conventions become a feature of catastrophe governance. Early efforts at transboundary pollution cooperation are precursors for later developments in international law that address the transboundary effects of industrial pollution caused by man-made accidents or natural disasters. Neither of these areas of co-operation, however, included requirements related to the provision of assistance or aid to countries suffering from transboundary epidemics or pollution.

\section{Humanitarian assistance, health and human rights}

Thinking on humanitarian assistance developed in relation to war and natural disasters, and the development of the policy and practice of humanitarian assistance is linked to human rights concepts. The human-rights approach holds that individuals have the right to be protected during conflicts and after disasters and to receive assistance when war or "acts of God" strike. Whether a wounded combatant, a civilian refugee from armed conflict or an individual left homeless by natural disaster, international efforts to ensure that assistance reaches such people connect to notions of human dignity captured by human rights thinking. This connection is not often explicit in the late nineteenth and early twentieth centuries because international humanitarian efforts began before the human rights revolution that occurred after the Second World War.

Political thinkers since the Enlightenment have argued that individuals possessed civil and political rights that shielded them from government power. The emergence of humanitarian assistance in an international context brought with it the notion that victims of armed conflict or disaster had a right to receive international assistance if their governments could not cope with their needs. The transnational aspect of this rights-based position connected the issue with international politics, raising state concerns about foreign interference with its military or domestic affairs. In the context of armed conflict, the International Red Cross movement served as a politically neutral source for provision of wartime 
humanitarian assistance that could support human dignity without provoking sensitivities embedded in sovereignty. The idea of a human right to receive international assistance also motivated those who pushed to create international mechanisms for disaster relief in the first half of the twentieth century, ${ }^{12}$ and these efforts had to confront state reluctance to base such mechanisms on a human right to receive foreign assistance because of the threat such notions posed to traditional conceptions of sovereignty. ${ }^{13}$ Despite state reluctance, the international humanitarian community continued to advocate for the human right to receive assistance. ${ }^{14}$

A rights-based approach also began to influence international efforts on protecting and promoting population and individual health. Given the importance of health in the provision of humanitarian protection and assistance, the shifting perspectives on health were directly relevant to humanitarian relief efforts. As noted above, the international sanitary conventions of the late nineteenth and first half of the twentieth centuries predominantly protected the economic and trade interests of countries. ${ }^{15}$ After the First World War, international health activities began to reflect ideas prevalent in the humanitarian assistance arena, especially the desire to provide assistance to populations in need of public health and healthcare services. This thinking matures in the human right to the highest attainable standard of health promulgated in the Constitution of the World Health Organization (WHO) in $1946 .{ }^{16}$ The right to health encompasses more than war and disaster-related contexts, and thus is broader than the right to receive assistance in times of armed conflict or other catastrophes. ${ }^{17}$ In addition, catastrophes produce the need to conduct triage with respect to individuals and health conditions, which produces tensions between the right to health and the exigencies of a massive humanitarian crisis. ${ }^{18}$ Nevertheless, the right to health directly supports the human right to humanitarian assistance when catastrophe strikes, because much of this assistance addresses specific health problems (e.g. spread of infectious diseases in affected populations) and determinants of health conditions (e.g. food, water, shelter and sanitation).

12 Hutchinson, "International Relief Union", above note 4, p. 261.

13 See ibid. for a historical account of how the proposal for an international relief organization was systematically weakened to suit states' interests and their sovereignty.

14 The Code of Conduct for the International Red Cross and Red Crescent Movement and NGOs in Disaster Relief expressed the human rights principle and commitment in stating that " $\mathrm{t}] \mathrm{h}$ he right to receive humanitarian assistance, and to offer it, is a fundamental humanitarian principle which should be enjoyed by all citizens of all countries." Code of Conduct for the International Red Cross and Red Crescent Movement and NGOs in Disaster Relief, available at http://www.ifrc.org/publicat/conduct/ code.asp (last visited 24 April 2007).

15 Although commercial interests played a central role, other factors contributed to the development of international co-operation on epidemic diseases. See, e.g., Mark Harrison, "Disease, diplomacy and international commerce: the origins of international sanitary regulation", Journal of Global History, Vol. 1 (July) (2006), p. 197.

16 Constitution of the World Health Organization, 22 July 1946, in World Health Organization, Basic Documents, 40th edn, World Health Organizaion, Geneva, 1994, p. 1.

17 For analysis on the scope of the right to health, see Brigit C. A. Toebes, The Right to Health as a Human Right in International Law, Hart Publishing, Oxford, 1999.

18 Waldman, above note 2, p. 563. 


\section{The securitization of health and disaster relief}

What emerged in the past ten to fifteen years is a different way of thinking about epidemic diseases and disasters. States, intergovernmental organizations and non-governmental organizations increasingly conceptualized epidemics and disasters as threats to human, national and global security. This phenomenon is complex and controversial, but it produces a transformed governance perspective on catastrophic events. As described above, previous frameworks for thinking about epidemics, transboundary pollution and natural disasters did not view these events in security terms. Only humanitarian assistance to victims of armed conflict had security implications, and this context made the International Red Cross movement's political neutrality critical to its ability to deliver humanitarian aid and to play a role in the development of international humanitarian law.

For this article's purposes, the securitization of health and disaster relief arises from changes in thinking about threats from nuclear, radiological, biological and chemical (NRBC) weapons, infectious diseases and natural disasters. These changes converged to emphasize the security-based need to scale up prevention, protection and response capabilities, particularly as they relate to population health. This convergence emerges from the breakdown of the traditional policy and governance "stovepipes" built to deal with NRBC weapons, infectious diseases and natural disasters (figure 1). States addressed NRBC weapons through an arms control approach that sought to reduce the threat these weapons pose to national and international security. ${ }^{19}$ Countries paid little serious attention to preparing to
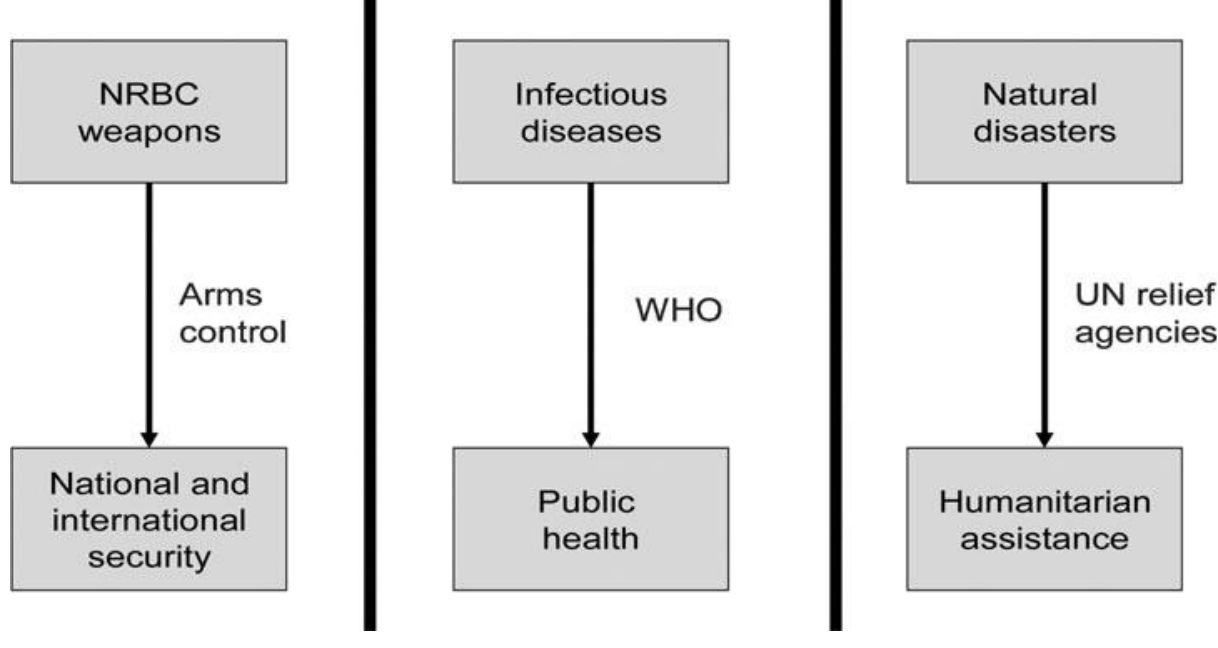

Figure 1 Policy and governance "stovepipes"

19 The leading arms control treaties for NRBC weapons are the Geneva Protocol for the Prohibition of the Use in War of Asphyxiating, Poisonous or Other Gases, and of Bacteriological Methods of Warfare, 17 June 1925, League of Nations Treaty Series, Vol. 44, p. 65; Treaty on the Non-Proliferation of Nuclear 
respond to the aftermath of NRBC weapons use, ${ }^{20}$ and arms control treaties contain no or only general provisions that address responses to the use of the weapons in question. ${ }^{21}$

The rise of a new kind of terrorism in the 1990s challenged the traditional arms control approach to NRBC weapons, and forced countries to think about the need to prepare for and respond to possible NRBC attacks. States began (i) to realize that terrorist interest in potentially catastrophic violence reflected changes in the political or military motivations actors may have to develop, acquire, or use NRBC weapons; (ii) to appreciate that the technological feasibility of NRBC weapon development, acquisition and use was increasing; and (iii) to grasp the vulnerabilities of their societies to NRBC terrorism. What states confronted was a new NRBC weapons threat profile which the traditional arms control approach was ill-equipped to address, and that pointed to the need to focus more attention and resources on preparedness and response capabilities, especially concerning public health (figure 2). Thus the ability to respond to, and recover from, a NRBC

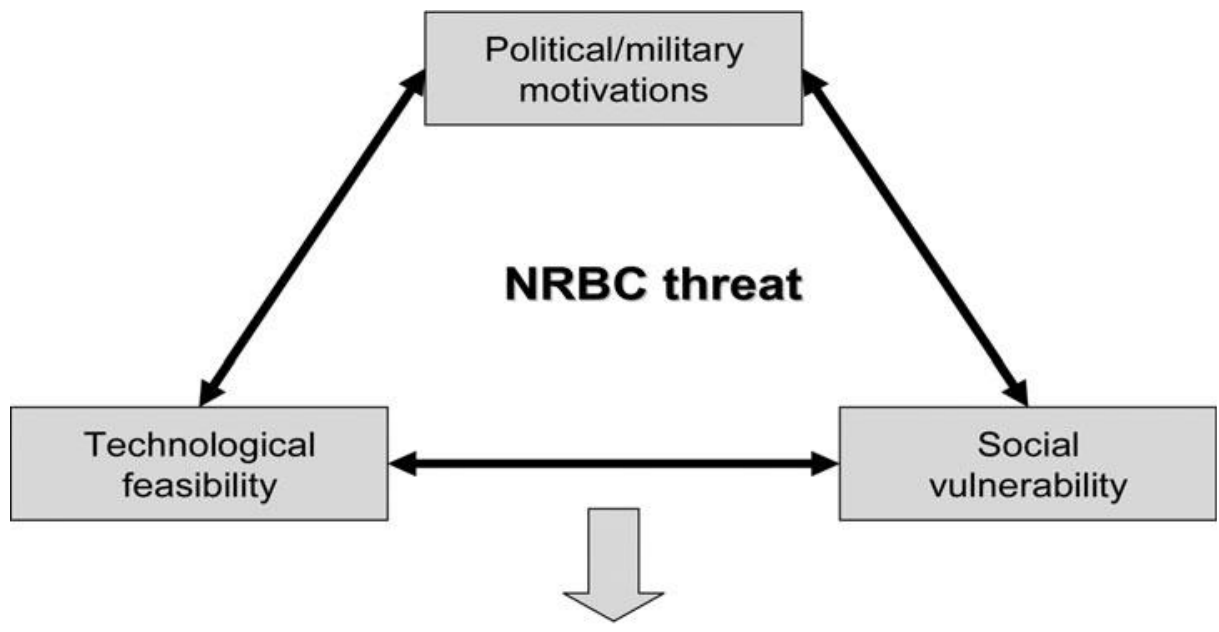

\section{Public health preparedness and response}

Figure 2 New NRBC threat profile

Weapons, 1 July 1968, International Atomic Energy Agency Information Circular INFCIRC/140, 22 April 1970; Convention on the Prohibition of the Development, Production, and Stockpiling of Bacteriological (Biological) and Toxin Weapons and on Their Destruction, 10 April 1972, International Legal Materials, Vol. 11 (1972), p. 309; and Convention for the Prohibition of the Development, Production, Stockpiling and Use of Chemical Weapons and on Their Destruction, 13 January 1993, International Legal Materials, Vol. 21 (1993), p. 800.

20 Some policy attention was paid to civil defence strategies with respect to possible nuclear attack, but governments tended to marginalize such strategies in their overall attempts to prevent the use and spread of nuclear weapons. On civil defence in various countries during the cold war, see Lawrence J. Vale, The Limits of Civil Defence in the USA, Switzerland, Britain, and the Soviet Union: The Evolution of Policies since 1945, St. Martin's Press, New York, 1987.

21 For example, the Convention on the Prohibition of the Development, Production, and Stockpiling of Bacteriological (Biological) and Toxin Weapons and on Their Destruction, above note 19, provides in 
attack with health and other forms of assistance became critical to national and homeland security policies. ${ }^{22}$

Similarly, the policy "stovepipe" for infectious diseases underwent radical change. As noted earlier, international co-operation on infectious disease threats has a long history, but rarely, if ever, in this long history were infectious diseases considered security threats, even in the wake of global disease catastrophes such as the 1918-19 influenza pandemic. Infectious diseases were public health problems handled through technical agencies trained in epidemiology and medicine. The public health approach to infectious diseases never connected its efforts to arms control strategies, even in connection with the threat posed by biological weapons. As noted above, the transformation in policy concerning NRBC weapons brought the worlds of public health and security together seriously for the first time.

In addition, the securitization of public health developed through the reconceptualization of naturally occurring infectious diseases as threats to human, ${ }^{23}$ national ${ }^{24}$ and global security. ${ }^{25}$ Analyses for reforming the United Nations stressed the linkage between security and public health. The UN Secretary-General's High-Level Panel on Threats, Challenges, and Change argued, for example, that "the security of the most affluent State can be held hostage to the ability of the poorest State to contain an emerging disease". ${ }^{26}$ This securitization process also unfolded in the revision process of the International Health RegulationsWHO's international legal rules on infectious disease control that had their origins in the old international sanitary conventions. ${ }^{27} \mathrm{WHO}$ framed the new International Health Regulations as an instrument designed to strengthen global health security. ${ }^{28}$ This reconceptualization, and others that frame public health problems as security threats, ${ }^{29}$ elevated public health capabilities to the level of security policy.

Article VII that "[e]ach State Party to this Convention undertakes to provide or support assistance, in accordance with the United Nations Charter, to any Party to the Convention which so requests, if the Security Council decides that such Party has been exposed to danger as a result of violation of the Convention."

22 See, e.g., White House, National Strategy for Homeland Security, White House, Washington, DC, 2002.

23 Commission on Human Security, Human Security Now: The Final Report of the Commission on Human Security, United Nations, New York, 2003 (linking infectious diseases and human security).

24 White House, National Security Strategy, above note 22, and White House, National Security Strategy of the United States of America, White House, Washington, DC, 2006 (including infectious disease threats as national security issues).

25 Laurie Garrett, “The Next Pandemic?", Foreign Affairs, Vol. 84 (4) (2005), p. 3 (warning of the global security implications of pandemic influenza).

26 A More Secure World: Our Shared Responsibility (Report of the Secretary-General's High-Level Panel on Threats, Challenges and Change), United Nations, New York, 2004, p. 14.

27 See World Health Organization, International Health Regulations (2005), Geneva, 2006. For analysis of the new International Health Regulations, see David P. Fidler, "From international sanitary conventions to global health security: the new International Health Regulations", Chinese Journal of International Law, Vol. 4 (2) (2005), p. 325.

28 See Fidler, above note 27 , pp. 347-55.

29 See, e.g., G. John Ikenberry and Anne-Marie Slaughter, Forging a World of Liberty under Law: U.S. National Security in the 21st Century, Princeton project on National Security, Princeton, 2006, p. 51 (arguing that "American national security in the 21 st century ... is likely to be threatened by pathogens as much as [by] people."). The securitization process has also been prominent with respect to the HIV/ AIDS pandemic. See, e.g., Laurie Garrett, HIV and National Security: Where are the Links? Council on Foreign Relations, New York, 2005. 
The "stove pipe" in which policy on natural disasters developed also experienced change through new thinking about how states should approach natural disasters. Traditional perceptions of natural disasters considered them episodic, self-contained events that triggered the need for humanitarian assistance. Thus, as depicted in figure 1, disaster relief was handled as a humanitarian matter by agencies tasked with this mission. The increasing frequency and harsher impact of natural disasters convinced many involved in disaster planning and relief that countries needed to rethink how they approached this policy area. This rethinking involved seeing natural disasters as threats to core political interests of states, including national security and economic development, rather than as occasions for episodic humanitarianism. Natural disasters also came to be seen as threats under different concepts of security, such as human security, ${ }^{30}$ national security ${ }^{31}$ and global health security. ${ }^{32}$

As part of the reconceptualization of disaster policy, analyses began to stress the importance of in-depth disaster governance, which includes preventing disasters (if possible), protecting against disasters that cannot be prevented (e.g. earthquakes) and building robust response and recovery capabilities to address the damage done by disasters. ${ }^{33}$ Critical to the securitization of disaster preparedness and response, and its linkages to strategies for economic development, is upgrading governmental, intergovernmental and non-governmental capabilities to handle large-scale disasters, especially capabilities to address population and individual health problems disasters spawn. As the Hyogo Framework for Action on disaster policy asserted, "in order to meet the challenges ahead, accelerated efforts must be made to build the necessary capacities at the community and national levels to manage and reduce risk" ${ }^{34}$

The end result of the collapse of the traditional "stovepipes" for arms control, public health and humanitarian assistance has been convergence on using security concepts to frame the policy debate and highlighting the importance of capabilities to respond to the health and humanitarian challenges the different sources of catastrophic events could generate (figure 3).

NRBC attacks, infectious disease epidemics and natural disasters are all potential sources of catastrophic events, so the securitization phenomenon represents an important development in thinking about catastrophe governance. This development, in many respects, resonates with the devastating nature of catastrophes and the problems such devastation poses for the security of

30 Amitava Basu, "Human security and disaster management", Insecurity Forum, 8 November 2005, available at http://insecurityforum.org/shirdi/670/ (last visited 24 April 2007).

31 White House, National Security Strategy, above note 24, p. 47 (including destruction caused by floods, hurricanes, earthquakes, or tsunamis as national security issues).

32 World Health Organization, International Health Security Issues Paper: Invest in Health, Build a Safer Future, World Health Organization, Geneva, 2007, p. 8 (listing natural disasters as a threat to international health security).

33 For an example of the comprehensive approach to disaster policy, see the Hyogo Framework for Action 2005-2015: Building the Resilience of Nations and Communities to Disasters, UN Doc. A/CONF.206/L.2/ Rev.1, 2 February 2005, available at http://www.unisdr.org/eng/hfa/hfa.htm (last visited 24 April 2007).

34 Ibid., para. 3. 


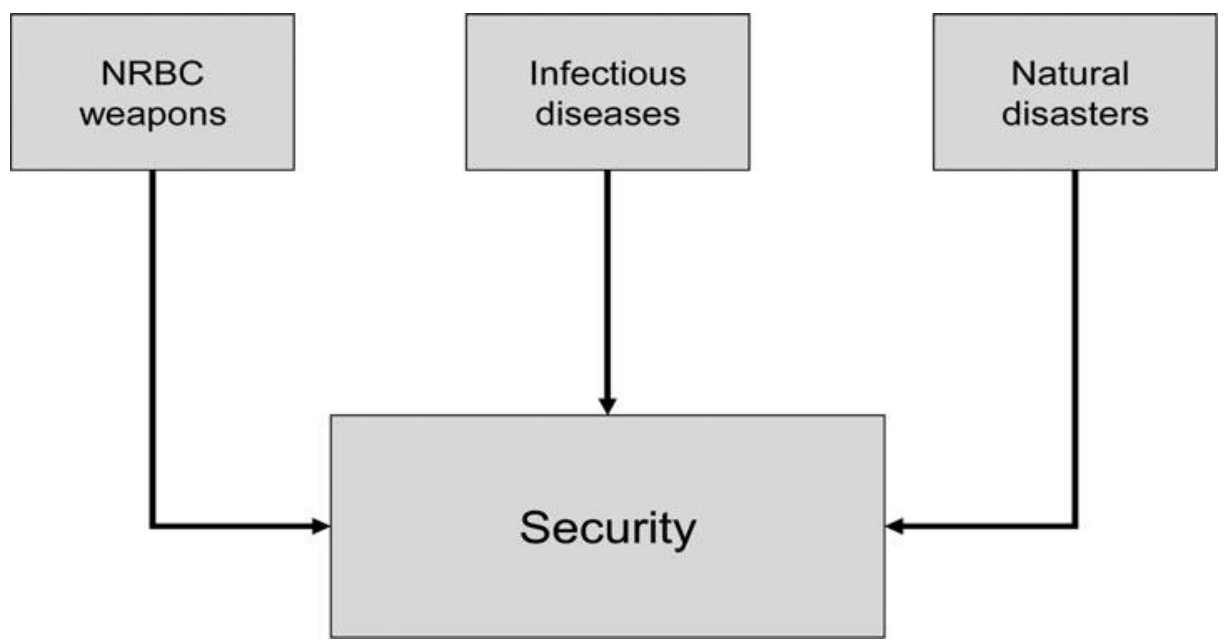

Figure 3 Policy convergence on security concepts

individuals, societies and governments. Yet the securitization of health and disaster relief suggests that, historically, security considerations did not inform the development of mechanisms for catastrophe governance. Even in the context of humanitarian assistance in armed conflict, states did not typically view such assistance as contributing to their national security. Too often states subordinated the need for humanitarian assistance to military or political objectives that required more death and destruction to produce the level of security desired. What is the explanation for the fact that security frameworks have only recently affected policy thinking about catastrophe governance?

Answers to this question could take many analytical routes, but some basic factors require emphasis. The securitization of health and disaster relief indicates that policy makers have moved away from traditional notions of security that are tied to violent military threats from foreign powers. ${ }^{35}$ Even in the midst of catastrophic war, the central security threat is not the physical destruction caused by armed conflict but the military forces of the enemy actually causing the destruction. This reality explains why military strategy traditionally focused on how to defeat the enemy's armed forces. The broadening of the security paradigm witnessed in the last ten to fifteen years reveals the merging of two developments. First, with the end of the cold war, risk of total war between states subsided. Second, states realized that the material damage terrorist attacks, epidemics and natural disasters could inflict on societies, including rich countries, was enormous, increasing and threatening to trigger unpredictable political and economic consequences that governments would control only with great difficulty.

35 Peter Bergen and Laurie Garrett, Report of the Working Group on State Security and Transnational Threats (Princeton Project on National Security, 2005), available at http://www.wws.princeton.ed/ppns/ conferences/reports/fall/SST.pdf (last visited 24 April 2007). 
The broadening of the security paradigm has other features. The conventional view of security policy focused on the security of the state. The post-cold war period witnessed an explosion in efforts to expand the notion of security beyond state security. As a result, policy debates began to refer to, among others, human security, environmental security, health security, sustainable security and comprehensive collective security. Broader notions of security accommodate a diverse array of political interests and groupings, from those that view terrorism as a non-traditional security threat to those that want to use security to address the "root causes" of world problems. The frequency of the use of "security" to reframe policy debates across different governance areas speaks to the perceived power of this concept in political circles. The many efforts to use security to recharacterize policy problems have produced scepticism about this phenomenon. Responding to recent arguments that climate change is a security issue, Barrett noted that "[e]verything's a national security issue these days. It's a bit of a marketing ploy." 36

The belief that framing an issue as a security threat can lead to more political attention, economic resources and policy action is strong, and this belief has been called "securitism". ${ }^{37}$ Ironically, cynicism only reinforces the perceived strength of the security argument. As noted about the power of securitism in the world of public health,

Some may doubt the sincerity of some efforts to connect public health and security, such as the cynical playing of the "security card" by public health officials and advocates desperate for more political attention and economic resources. The deeper the cynicism the stronger the argument about the triumph of public health securitism becomes. Such cynicism reflects a coldly calculated decision that public health can be improved by appealing to security concepts and considerations. ${ }^{38}$

Globalization also plays a role in stimulating use of the security framework. A globalized world makes terrorism and epidemic disease fluid, mobile and unpredictable threats, decreasing the prospect that prevention efforts can succeed. Likewise, scientists assert that natural disasters agitated by globally generated anthropogenic causes (e.g. the frequency and severity of storms linked to climate change) raise the possibility that some natural disasters have, like terrorism and epidemic disease, become more unpredictable, unpreventable and dangerous. From broader security perspectives, we also glimpse the potential for the "perfect storm": the weakening of governance capabilities by catastrophic events increases the likelihood of political unrest and violence, whether in the form

36 Quoted in Karen Kaplan and Thomas H. Maugh, "Climate change called a security threat", Los Angeles Times, 17 April 2007, available at http://www.latimes.com/news/nationworld/nation/la-sci-defense 17apr17,1,6584970.story?track= rss (last visited 24 April 2007).

37 David P. Fidler, "A pathology of public health securitism: approach pandemics as security threats", in Andrew F. Cooper, John J. Kirton, and Ted Schrecker, eds., Governing Global Health: Challenge, Response, Innovation, Ashgate Publishing, Aldershot, 2007, p. 41.

38 Ibid., p. 44. 
of insurgencies against failing governments, terrorism or interstate warfare. The increasing difficulties related to preventing catastrophic events focuses security interests on protection and response capabilities. This dynamic places health, humanitarian assistance and their interdependency prominently on the new agenda of security in complex and controversial ways.

\section{Catastrophe governance under a security paradigm: implications for health and humanitarian assistance}

\section{Securitization and governance priorities}

The securitization of health and disaster relief reflects not only greater awareness of the damage that catastrophic events could inflict on societies but also a normative shift with respect to creating incentives for governments, international organizations and non-state actors to take more vigorous action. Framing health and disaster relief as security challenges is a strategy to achieve reprioritization in governance processes. The appeal of security-based arguments derives from the priority policy makers are perceived to give to security threats. Framing disease problems or transboundary pollution from industrial accidents as irritants to economic and trade interests, or disaster relief as a human rights obligation, has not stimulated states to give these matters priority in national or international politics. Recasting these problems as security threats provides the opportunity to change the nature of governance discourse about these problems and how to organize political responses to them.

Securitization in the context of catastrophe governance has, however, complex consequences that require careful attention. Earlier frameworks had complicated dynamics as well, but of a different sort. For example, conceiving humanitarian assistance as linked to the fulfilment of human rights means that such assistance must always be provided when needed, whatever the source or political circumstances of the crisis. This logic feeds into the political neutrality that historically characterized the provision of humanitarian assistance in times of war or in the aftermath of natural disasters. Yet, as the lack of development of international law on disaster relief suggests, ${ }^{39}$ states have consistently been wary of exposing their sovereignty to foreign humanitarian relief efforts without retaining as much control as possible over such efforts. In the eyes of advocates for better humanitarian responses to crises, state predilection for control is a barrier to overcome through new mechanisms and rules that limit sovereignty's remit over the need to deliver relief as quickly and effectively as possible.

Securitization of health and disaster relief in the context of catastrophes makes the relationship between sovereignty and the provision of health and

39 See, e.g., International Federation of Red Cross and Red Crescent Societies, World Disasters Report 2000, Geneva, 2000, p. 157 (arguing that disaster relief is a "long-neglected facet of international law", and that "it is unlikely that any other challenge looming so large in world affairs has received so little attention in the legal realm"). 
humanitarian assistance more complicated. Exploring this complexity requires breaking down catastrophe governance analytically in order to identify factors that influence a security-based approach to health and humanitarian assistance. As explained more below, the source, scale and severity of a catastrophe will affect the security calculations of a sovereign state with respect to preventing, protecting against and responding to catastrophic events. These calculations determine the shape of policies and thus the effectiveness and sustainability of governance responses.

\section{The prevention, protection and response functions of catastrophe governance}

Whether the threat comes from a NRBC terrorist attack, industrial accident, disease epidemic, or natural disaster, policy makers need to focus on preventing, protecting against and responding to such events (figure 4). The securitization of health and disaster policy uses security arguments to encourage governments to give higher priority to the prevention, protection and response functions of catastrophe governance. The aim is to build in-depth defences against possible catastrophic events. Past approaches have not woven prevention, protection and response strategies into an integrated whole. In some cases, such as earthquakes and hurricanes, prevention is not possible and thus is not a focus of policy efforts. Where prevention is not possible, ensuring security depends on the ability to protect populations from harm (e.g. through early warning systems) and to respond to damage that occurs (e.g. provision of assistance to victims). In other

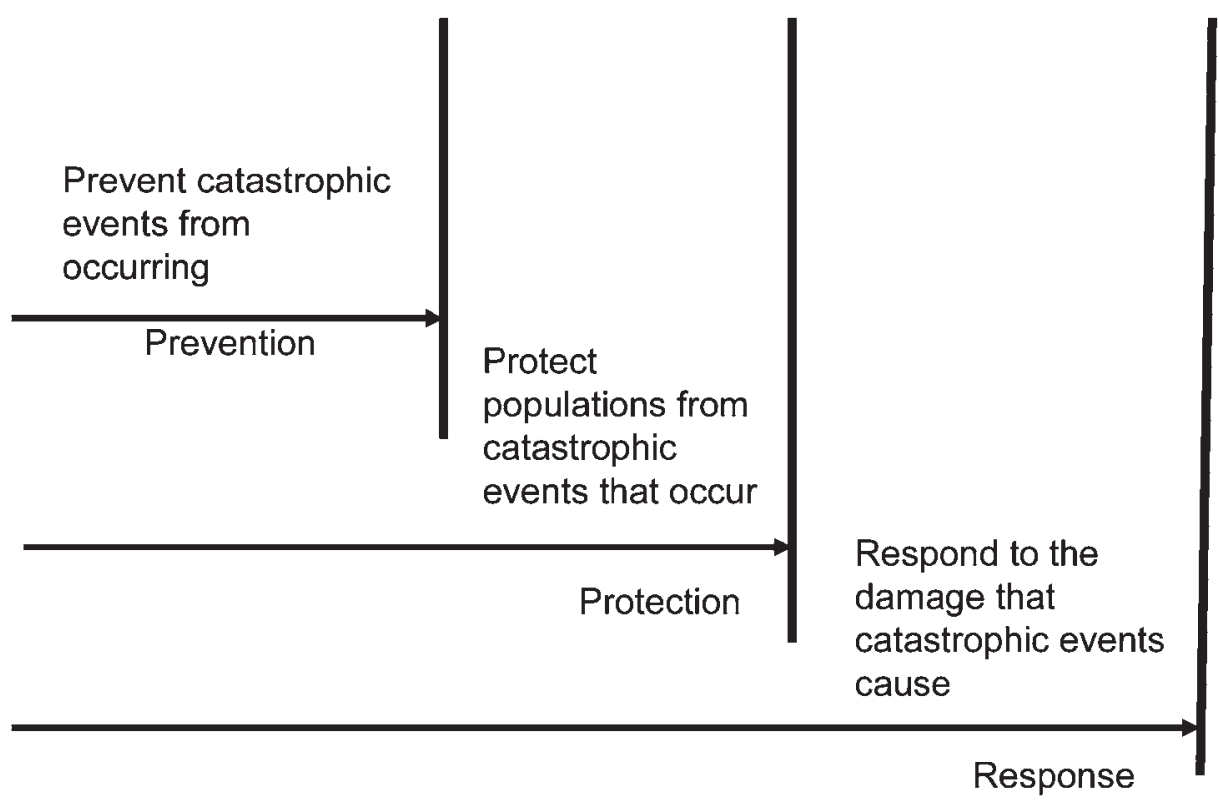

Figure 4 Prevention, protection, and response functions of catastrophe governance 
cases, as with arms control, policy mechanisms emphasized prevention (e.g. prohibitions on the development and proliferation of NRBC weapons) without incorporating protection objectives and response capabilities.

Looking at potential catastrophes through a security lens stresses the need for scaling up prevention (where possible), protection and response capabilities. The securitization of health provides a good example of this effect. The potential use of NRBC weapons by terrorists undermines the prevention aspects of traditional arms control treaties, forcing countries to transform prevention strategies to address this problem. In the United States the prevention imperative produced the doctrine of preventive self-defence, implemented in the 2003 invasion of Iraq, and the policy of aggressive interrogation of detained terrorist suspects. The threat of NRBC terrorism also sparked a massive effort in the United States to protect the population (e.g. the smallpox vaccination campaign, improving surveillance and early warning systems) and to improve the ability of the public health system to respond to NRBC attacks (e.g. stockpiling drugs and medical supplies, and providing incentives for the development of countermeasures for NRBC weapons). Experts believed that many of these security approaches to the NRBC terrorism threat also strengthened the United States' ability to protect against, and respond to, large-scale naturally occurring infectious diseases, such as pandemic influenza. ${ }^{40}$

\section{Security and the prevention function}

Preventing catastrophes makes sense, of course, without framing the problem in security terms. The security lens, however, gives prevention a sharper edge than it has, for example, in the context of preventing transboundary pollution from industrial accidents. ${ }^{41}$ To prevent biological calamity, a security approach may intentionally restrict or infringe sovereignty, community interests and individual rights. To avoid potentially significant and dangerous efforts to provide assistance to victims of NRBC terrorism or disease epidemics, aggressive prevention measures look attractive, despite the short-term costs they create. The securityrelated prevention imperative raises difficult questions that policy makers cannot avoid. For example, to prevent extensively drug-resistant tuberculosis (XDR-TB) from becoming a global health disaster, should public health authorities in affected countries be more aggressive in using compulsory measures to prevent further transmission $?^{42}$ If terrorist groups remain interested in NRBC weapons, should not

40 Christopher F. Chyba, "Toward biological security”, Foreign Affairs, Vol. 81 (3) (2002), p. 132 (arguing that "many of the steps that are needed to prepare for bioterrorism will also improve recognition of and responses to natural disease outbreaks. Spending on biological defences therefore represents a win-win situation in which society benefits even if no further bioterrorist attacks take place").

41 See, e.g., Convention on Transboundary Effects of Industrial Accidents, 17 March 1992, International Legal Materials, 1992, Vol. 31, p. 1330.

42 Jerome A. Singh, Ross Upshur, and Nesri Padayatchi, "XDR-TB in South Africa: no time for denial or complacency", PLoS Medicine, 2007, 4(1):e50.doi:10.1371/journal.pmed.0040050 (raising the need for compulsory measures for persons infected with XDR-TB). 
states use law enforcement and military capabilities aggressively to prevent catastrophic NRBC terrorism?

The prevention imperative also highlights the security importance of the source of a potential catastrophe. This imperative only gains policy traction in the context of anthropogenic catastrophes, such as the deliberate use of NRBC weapons or an industrial accident. Policy traction for prevention decreases the more the inputs of an anthropogenic catastrophe diffuse across communities, populations and countries. This diffusion, often accelerated by globalization, creates multiplying sources of anthropogenic inputs, which overwhelms national and international prevention capabilities. The diffusion effect is why policy makers generally concede that states cannot prevent pandemic influenza from emerging, drug-resistant strains of microbes from developing and spreading or (at this point) climate change from occurring. The diffusion effect is also why many governments have acted with urgency against the spread of global terrorist networks.

The source of a potential catastrophe is also important for prevention, because different sources create different prevention needs. Military and law enforcement actions to prevent NRBC terrorism do not contribute to efforts to prevent the spread of a virulent, naturally occurring infectious disease, and vice versa. Catastrophe prevention requires its own prioritization, even when states consider both NRBC terrorism and virulent epidemics to be security threats. The security framework tends to privilege prevention of deliberate catastrophes over catastrophes that have no "return address" because the intentional sources threaten violent attacks on societies. This reality mirrors how security thinking has historically operated; preventing or deterring violent threats has long garnered more attention and resources from governments than preventing epidemics or industrial accidents.

\section{Security and the protection function}

The need for protection strategies vis-à-vis catastrophes flows from the realization that prevention will be impossible (e.g. tsunamis cannot be prevented) or only partially effective. In short, events with catastrophic potential will occur. Protection strategies work, however, to "harden the target" against such events and, thus, to mitigate the resulting damage. Thus effective protection reduces the potential dangers and costs that response actions create for governments and societies. Overall, protection policies decrease the likelihood that a dangerous event will seriously threaten a country's security.

In public health, vaccination represents a protection strategy of proven efficacy. Dangerous microbes will circulate in societies, but, sometimes, vaccines render such microbes harmless to vaccinated populations. Sufficiently broadbased vaccination creates "herd immunity" in the population, increasing the level of protection beyond those vaccinated. Building codes that require commercial and residential structures constructed in earthquake zones to withstand earthquakes constitute protection strategies. Zoning laws that minimize population exposure to flooding protect societies from potentially catastrophic loss of life and 
property. A cross-cutting protection strategy involves early-warning systems (e.g. infectious disease surveillance, tsunami alert systems, weather warnings, notification procedures for industrial accidents) that permit advance notice of impending harm.

Protection strategies make sense as a general policy matter, but we need to consider such strategies in the light of the securitization framework. The first point a security focus makes clear is that protection strategies for different potential large-scale events have little overlap. In short, producing multi-catastrophe synergies through protection policies is not possible. A tsunami-alert system contributes nothing directly to surveillance systems for pandemic influenza, and vice versa. Monitoring systems for earthquakes do not provide early warning for hurricanes, and vice versa. Radiation detectors at ports of entry do not strengthen a government's ability to detect illicit activities related to chemical terrorism, and vice versa.

The one area where experts have discussed the potential to create such synergies involves security threats from biological terrorism and naturally occurring infectious diseases. Literature on biosecurity contains assertions that building stronger defences against biological weapons contributes to stronger defences against infectious disease epidemics. ${ }^{43}$ In terms of the objective of protection, synergies can exist, but they are not as robust or frequent as some have claimed. The strongest potential synergies arise in the area of disease surveillance, because early, rapid and accurate identification of a microbial threat contributes to protection of populations against infectious disease, whatever the source of the pathogen's presence in societies. The decision to expand the scope of the new International Health Regulations to include intentional as well as naturally occurring disease events recognizes the potential synergies disease surveillance can produce.

Outside surveillance, protection strategies for biological terrorism and for naturally occurring infectious diseases do not produce policy synergies. The smallpox vaccination campaign in the United States in 2003 illustrates this point. The US government sought to vaccinate healthcare personnel and first responders against terrorist use of smallpox. ${ }^{44}$ This effort was a protection strategy against biological terrorism, but the vaccination campaign created no synergies or benefits for protecting US populations from naturally occurring infectious diseases. Similarly, annual influenza vaccination campaigns do not strengthen defences against biological terrorism that utilizes anthrax.

The lack of cross-cutting synergies in protection strategies for different catastrophes, and the limited nature of synergies within the realm of biosecurity, force governments to develop priorities for protection efforts. As noted earlier, the

43 In Larger Freedom: Towards Development, Security and Human Rights for All: Report of the SecretaryGeneral, UN Doc. A/59/2005, March 21, 2005, p. 27 (UN Secretary-General asserting that measures to strengthen public health "have a double merit: they would both help to address the scourge of naturally occurring infectious disease and contribute to our safety against manmade outbreaks").

44 See, e.g., Committee on Smallpox Vaccination Program Implementation, The Smallpox Vaccination Program: Public Health in an Age of Terrorism, National Academies Press, Washington, DC, 2005. 
security framework is, in many ways, a template for prioritization, and the framework, in the protection area, tends to privilege strategies connected to the intentional use of NRBC weapons as opposed to protection against, for example, natural disasters, even though these disasters could produce greater death, disease and destruction than, say, chemical terrorism or detonation of a "dirty bomb".

Beyond the source of an event, the potential scale and severity of the threat affects prioritization for protection strategies under a security framework. The greater the potential geographical impact and the material damage a catastrophic event threatens, the more likely it is to register as a security priority. Many factors affect the scale and severity of a disaster event, including the mobility of the threat, its impact on life, property and social order, and the means governments have to respond to it. These factors help explain why many policy makers emphasize pandemic influenza as a security threat. Its mobility, potential to cause death and disorder on a frightening scale, the scarcity or non-existence of antivirals or vaccine, and ability to overwhelm response capacities gives pandemic influenza a more dangerous profile than many types of disasters, including industrial accidents or large-scale disasters such as the Indian Ocean tsunami.

The lack of synergies in the area of protection against catastrophes and the need to prioritize protection strategies create significant governance burdens nationally and internationally. These burdens are particularly acute for developing and least-developed countries, which are the least equipped to shoulder the responsibility of engaging in systematic and sustainable catastrophe protection policies. From the perspective of developing and least-developed countries, catastrophe protection against unpredictable events that may happen tomorrow or decades in the future competes with more pressing and immediate security and other political, economic and social problems. ${ }^{45}$ Therefore countries with greater vulnerability have the weakest capabilities in the face of catastrophic events.

This reality raises, of course, the need for international co-operation on protection strategies. The security framework affects this need as well. By design, framing catastrophes in security terms encourages countries to rethink their own security policies. This self-regarding focus does not preclude international cooperation, as recognition of the need to build global disease surveillance capabilities attests. The security focus does, however, mean that international co-operation is most likely to occur most seriously with respect to those catastrophic events that affect a broad range of countries, namely events with transnational scale and order-disturbing severity. Developed countries' willingness to provide significant assistance to developing countries competes with the developed countries' needs to build and sustain their own capabilities to protect against and respond to the security threats that such catastrophic events pose for them. Hurricane Katrina in the United States illustrated the vulnerabilities that developed countries face and the scale of the resources these countries require to reduce their own vulnerabilities. 
In short, the security framework does not convince developed countries vastly to increase assistance for catastrophe protection or response for developing countries because the developed countries too feel threatened and unprepared. Developed countries tend to target increased assistance for developing countries towards protection capabilities for transnational threats that could potentially affect populations in developed countries (e.g. infectious disease surveillance). For catastrophes in developing countries that remain localized in scale and severity, the security framework does not significantly increase the incentives for developed countries to help developing countries. The dynamics of protection strategies under a security approach reveal developed countries exercising sovereignty in ways that privilege their security over the security of other nations. This outcome is not surprising when catastrophes are perceived as real security threats to sovereign states. Overall, more attention is paid to catastrophe preparedness under a security framework, but not in ways that significantly reduce inequalities in resources and capabilities between developed and developing countries.

\section{Security and the response function}

The last function served by catastrophe governance is response. The premise is that neither prevention (where possible) nor protection will eliminate the possibility of widespread damage from a catastrophic event which necessitates the need to respond to victims with assistance. The response function of catastrophe governance most closely relates to the provision of disaster relief and humanitarian assistance in the wake of large-scale tragedies. Providing such relief and assistance has, as noted earlier, long been a subject of national governance and international co-operation, but, traditionally, the justification for it connected to humanitarian and human rights concerns, not security. Under a security approach, effective provision of assistance in the wake of catastrophic events becomes important for maintaining political order, economic infrastructure, social stability and governmental legitimacy. As with prevention and protection strategies, the security perspective heightens the political importance of the provision of assistance beyond traditional humanitarian and moral motivations.

Viewing catastrophic response capabilities through the security lens creates some interesting, and complex, issues. Before probing these issues, understanding some problems that affected humanitarian assistance in the past proves useful. As the International Federation of Red Cross and Red Crescent Societies has argued, states and international organizations have not developed much international law on humanitarian and disaster relief outside the context of armed conflict. ${ }^{46}$ A key reason for this lack of international legal development has been the reluctance by states to weaken their ability to control whether foreign entities provide assistance in their territories. This strong sense of sovereignty

46 International Federation of Red Cross and Red Crescent Societies, above note 39; International Federation of Red Cross and Red Crescent Societies, International Disaster Response Laws, Principles, and Practice: Reflections, Prospects, and Challenges, International Federation of Red Cross and Red Crescent Societies, Geneva, 2003. 
opposed attempts to base humanitarian assistance on the idea that individuals had a human right to receive adequate assistance after a disaster, including foreign assistance if the state affected could not provide sufficient relief. This unwillingness to weaken sovereignty's hold on humanitarian assistance continued to be robust even as international capabilities, particularly those of non-state actors, to deliver such assistance expanded and improved. ${ }^{47}$ Thus, even before the securitization process takes hold, the response function of catastrophe governance was highly sensitive to sovereignty concerns.

Similar dynamics developed with respect to the international human right to health. Although proclaimed in the WHO Constitution and incorporated into international human rights treaties, the right to health has suffered from vagueness and lack of specificity about what it requires from states. Like many economic, social and cultural rights, the right to health has an aspirational quality to it, leaving sovereign states subject to this right with great discretion in determining how they would comply with it. Serious efforts to clarify the right to health's requirements have really only occurred in the past decade, ${ }^{48}$ and these efforts have generated arguments that call for more vigorous attention to the right's meaning and application. ${ }^{49}$ These efforts parallel advocacy of the development of international law on disaster relief. ${ }^{50}$

Framing disaster relief and humanitarian assistance as security issues may, at first glance, appear to reinforce the strong sovereignty position taken by states in the past. Securitization may, however, have more complex effects. The rigid sovereignty stance of states in the past perhaps flowed from security and other political concerns about foreigners providing disaster relief or humanitarian assistance. This perspective did not necessarily view the disaster and its aftermath as the security threat but rather the potential foreign interference the disaster might create. The securitization paradigm considers the catastrophe itself to be the security issue, especially with respect to large-scale and severe catastrophes. Under this view, effective response capabilities become security assets rather than moral and humanitarian tools that may trigger negative political and security externalities. From a security perspective, states may have more rather than less incentive to rethink the manner in which they approached the provision of disaster relief and humanitarian aid in the past.

The aftermaths of the Indian Ocean tsunami and Hurricane Katrina help to reinforce this observation. The massive international response to the

47 Ajun Katoch, "International natural disaster response and the United Nations", in International Disaster Response Laws, Principles, and Practice, above note 46, pp. 49-50 (analysis of UN General Assembly resolutions from 1981 until 2002, showing increasing emphasis on sovereignty).

48 See, e.g., General Comment No. 14: The Right to the Highest Attainable Standard of Health, UN Doc. C/C.12/2000/4, CESCR General Comment 14, July 4, 2000.

49 See, e.g., the work of the Special Rapporteur of the Commission on Human Rights on the right of everyone to the enjoyment of the highest attainable standard of physical and mental health, at http:// www.ohchr.org/english/issues/health/right/ (last visited 24 April 2007).

50 See International Federation of Red Cross and Red Crescent Societies, International Disaster Response Laws, Rules, and Principles Programme (IDRL), at http://www.ifrc.org/what/disasters/idrl/ (last visited April 24, 2007). 
devastation wrought by the tsunami not only saved thousands of lives but also sustained the Indonesian government's viability in the immediate aftermath of the cataclysm. The global capability to respond to something as massive as the death and destruction caused by the tsunami can be harnessed strategically by states to shore up their security interests in catastrophe response. Improving co-ordination and streamlining procedures for the provision of disaster relief and humanitarian assistance could, therefore, produce benefits from a security perspective, bringing the securitization perspective closer to those who, from a human rights and dignity perspective, want disaster relief provided more quickly and effectively.

Hurricane Katrina painfully illustrated the difficulties even the richest country on earth has with responding adequately to a foreseen and predicted catastrophic event. Countries with far fewer resources that face similar or worse possible catastrophic events need to see global disaster relief capabilities as critical security resources, because unilateral measures will, in many cases, not be effective. The smarter strategy is to view measures that enhance the utilization of foreign humanitarian assistance as security-enhancing moves in terms of the response function of catastrophe governance.

A security perspective on response capabilities also encourages states to improve their own national response capacities. Many countries have moved in this direction, particularly with respect to potential acts of NRBC terrorism and the possible emergence of pandemic influenza. International disaster relief efforts have also emphasized the importance of upgrading national response capabilities. ${ }^{51}$ Unlike with protection strategies, more possibilities exist for creating synergies in the area of response. Improving public health capabilities for responding to NRBC attacks can, for example, benefit responses to dangerous naturally occurring disease events, and vice versa. Stockpiles of medicines and other items can service responses to different kinds of catastrophe, as can multipurpose, all-hazards emergency communication technologies and facilities and response-training exercises that co-ordinate reactions of national and sub-national levels of government. The possibility for creating such response-capacity synergies strengthens a security-based outlook on the response function of catastrophe governance.

Complexity and controversy arise under a security perspective on response, however, when a catastrophic event involves suspected use of NRBC weapons. As noted earlier, this type of event triggers the highest level of national security concern, and a government subject to such an attack will not focus solely on responding to victims' needs. Unlike natural disasters, which typically have a defined source and end point (e.g. the hurricane dissipates after reaching land), governments do not know whether more attacks will follow an initial strike. The imperative to identify the perpetrators and perhaps prevent future attacks by, for example, restricting movement across national borders may complicate efforts to provide assistance to those harmed or adversely affected by the NRBC attack.

51 Hyogo Framework of Action, above note 33. 
Collecting evidence that may lead to attribution may take precedence over delivering aid to those harmed or displaced by the attack. In this context, governments may be especially wary of foreign involvement in response activities, which could lead to heightened restrictions, conditions and oversight on such involvement, which would produce delays in outside assistance reaching victims.

International interest or pressure to investigate the alleged use of NRBC weapons may exacerbate a government's national security concerns. Mechanisms exist in arms control treaties to authorize and facilitate investigations of alleged use of NRBC weapons, ${ }^{52}$ and the UN Secretary-General ${ }^{53}$ and the Security Council $^{54}$ have power to get involved in such matters. Concerns also arose that including intentional uses of chemical, biological and radionuclear substances in the scope of the new International Health Regulations would involve WHO in arms control matters and security politics to the detriment of its public health mission. ${ }^{55}$ How much the international community's desire to investigate, or actual international investigations themselves, would affect the speed and efficacy of response activities is not clear. The scale and severity of the crisis might influence this dynamic such that the larger and more devastating the catastrophe the more governments may privilege response needs over security imperatives related to identifying the perpetrators and preventing follow-on attacks.

Tension between security concerns and response efforts also exist with respect to naturally occurring infectious diseases. Controversy has arisen with respect to proposals that the UN Security Council should intervene when countries are not co-operating adequately with international efforts concerning dangerous biological events. ${ }^{56}$ Security Council involvement is premised on the idea that such events, even if naturally occurring, pose threats to national and international security. Similar possibilities for international intervention in a state's handling of a catastrophe arise under the principle of the responsibility to protect. $^{57}$ Although this principle developed mainly to justify humanitarian intervention to address large-scale atrocities (e.g. ethnic cleansing, genocide), the principle could also apply to legitimize intervention in cases of state unwillingness or inability to handle the aftermath of catastrophic events. Defenders of national

52 See, e.g., Convention on the Prohibition of the Development, Production, and Stockpiling of Bacteriological (Biological) and Toxin Weapons and on Their Destruction, above note 19, Article VI(1) ("Any State Party to this Convention which finds that any other State Party is acting in breach of obligations deriving from the provisions of the Convention may lodge a complaint with the Security Council of the United Nations").

53 For discussion of the UN Secretary-General's authority to investigate allegations of chemical weapons use, see Jez Littlewood, Investigating Allegations of CBW Use: Reviving the UN Secretary-General's Mechanism (Canadian Centre for Treaty Compliance Paper No. 3), December 2006.

54 The authority of the Security Council comes from the power it has under the UN Charter in addressing threats to international peace and security.

55 Fidler, above note 27, pp. 365-7.

56 A More Secure World, above note 26, p. 47 (proposing that the UN Security Council be prepared to intervene during suspicious or overwhelming outbreaks of infectious disease to facilitate an effective international response).

57 On the responsibility to protect, see International Commission on Intervention and State Sovereignty, The Responsibility to Protect, Ottawa, 2001. 
sovereignty, and those focused on humanitarian and health assistance, have expressed various levels of unease with the new mixture of security considerations and humanitarian responses. This unease reinforces the dramatic transformation in policy still unfolding in these areas of world affairs.

\section{Conclusion}

The relationship between health and humanitarian assistance has always been important to governance responses to catastrophic events. The interdependence of the protection of health and the provision of humanitarian assistance traditionally appeared most clearly through the human rights framework, under which individuals are deemed to have human rights to health services and other forms of humanitarian aid in the wake of disasters. This perspective remains strong in the international humanitarian assistance community. ${ }^{58}$ The emergence of a perspective that frames health and disaster relief as security issues has challenged the human rights ethos and influenced how states, international organizations and non-state actors conceive of catastrophe governance.

The extent to which the security approach has, in a relatively short period of time, entered into policy discourse about health and humanitarian assistance attests to the strength of its appeal. Arguments about whether the securitization of these policy areas is good or bad will continue, but, for the foreseeable future, security perspectives will remain influential in these realms. This article explored the controversies and complexities that securitization of health and disaster relief create for the governance challenges created by catastrophic events. Issues of source, scale and severity affect how the security perspective informs the sovereign state's approach to the prevention, protection and response functions of catastrophe governance.

At the heart of the securitization of health and disaster relief in the context of catastrophes is the objective of convincing states to improve national capabilities, strengthen international co-operation and develop resilient, sustainable governance strategies and capacities for catastrophic events. These tasks require building institutions and mechanisms for catastrophe governance, which is particularly difficult in international relations. ${ }^{59}$ Behind the embrace of a security perspective is the sense that prior frameworks, such as the limited regimes addressing cross-border harms or the human rights approach to health and disaster relief, were not sufficiently strong governance foundations. They lacked either the scope required or the ability to persuade states to give catastrophe governance higher political priority. State reluctance to develop seriously the right to health in international law or to craft international law on disaster relief

58 See, e.g., Sphere Project, Humanitarian Charter and Minimum Standards in Disaster Response, Sphere Project, Geneva, 2004, p. 16.

59 Barrett, above note 45, p. 527 (analysing the importance of institutions in preparing for catastrophes and the obstacles to creating effective ones). 
stemmed largely from concerns that such objectives posed potential threats to sovereignty.

The securitization strategy seeks to convince states that sovereignty is actually better served by the building of more robust national and international health and disaster relief systems. This objective creates, however, complexities to which no simple answers exist and controversies that are not easily resolved. Securitization of health and disaster relief is no panacea for the mounting challenges that catastrophe governance confronts nationally and internationally. Although a historic transformation in policy and practice, securitization in the context of catastrophe governance relates to a sobering reality: the potential for catastrophes is increasing, ${ }^{60}$ as is the human, political and economic damage they can inflict from local to global levels. What needs to increase are governance capabilities for preventing, protecting against and responding to these threats.

Unfortunately, viewing the threat through a security lens may not be avoidable, given the portents of what might be coming. We might be facing a Kantian dialectic with respect to catastrophe governance. In contemplating the potential for states to achieve perpetual peace, Kant argued that this long-held dream would only come to pass after states suffered through conflicts of increasing destructiveness and death. ${ }^{61}$ The security perspective has only arisen in response to the perception that man-made and naturally occurring catastrophes are increasingly dangerous for individual, societies, countries and the international community. Progress may not occur without increasing levels of pain, whether inflicted by terrorists, tectonic violence or the travails unleashed by a global climate out of balance. The extent to which securitization affects how catastrophes may haunt humanity in the future remains to be seen.

60 Richard A. Posner, "Efficient responses to catastrophic risk", Chicago Journal of International Law, Vol. 6 (Winter) (2006), p. 511 ("The probability of catastrophes resulting, whether or not intentionally, from human activity appears to be increasing because of the rapidity and direction of technological advances").

61 Immanuel Kant, Perpetual Peace: A Philosophical Sketch, 1795, available at http://www.mtholyoke.edu/ acad/intrel/kant/kantl.htm (last visited 24 April 2007). 